NBER WORKING PAPER SERIES

\title{
HOW DO REGULATORS INFLUENCE MORTGAGE RISK: EVIDENCE FROM AN EMERGING MARKET
}

\author{
John Y. Campbell \\ Tarun Ramadorai \\ Benjamin Ranish \\ Working Paper 18394 \\ http://www.nber.org/papers/w18394 \\ NATIONAL BUREAU OF ECONOMIC RESEARCH \\ 1050 Massachusetts Avenue \\ Cambridge, MA 02138 \\ September 2012
}

We gratefully acknowledge an Indian mortgage provider for providing us with the data, and many employees of the Indian mortgage provider, Santosh Anagol, Amit Bubna, Jishnu Das, Jennifer Huang, Ajay Shah, S. Sridhar, Usha Thorat, R. V. Verma, and Vikrant Vig for useful conversations and discussions. We thank seminar participants at the Econometric Society/European Economics Association Malaga Conference, the NBER Household Finance Summer Institute, IIM Bangalore, the World Bank, the Oxford-Man Institute of Quantitative Finance, Saïd Business School, the HKUST Household Finance Symposium, the NUS-IRES Real Estate Symposium, the NHB-CAFRAL Conference, and the NIPFP-DEA Conference on International Capital Flows for comments, the International Growth Centre and the Sloan Foundation for financial support, and Vimal Balasubramaniam for able research assistance. The views expressed herein are those of the authors and do not necessarily reflect the views of the National Bureau of Economic Research.

At least one co-author has disclosed a financial relationship of potential relevance for this research. Further information is available online at http://www.nber.org/papers/w18394.ack

NBER working papers are circulated for discussion and comment purposes. They have not been peerreviewed or been subject to the review by the NBER Board of Directors that accompanies official NBER publications.

(C) 2012 by John Y. Campbell, Tarun Ramadorai, and Benjamin Ranish. All rights reserved. Short sections of text, not to exceed two paragraphs, may be quoted without explicit permission provided that full credit, including (C) notice, is given to the source. 
How Do Regulators Influence Mortgage Risk: Evidence from an Emerging Market

John Y. Campbell, Tarun Ramadorai, and Benjamin Ranish

NBER Working Paper No. 18394

September 2012, Revised July 2013

JEL No. G21

\begin{abstract}
$\underline{\text { ABSTRACT }}$
John Y. Campbell

Morton L. and Carole S.

Olshan Professor of Economics

Department of Economics

Harvard University

Littauer Center 213

Cambridge, MA 02138

and NBER

john_campbell@harvard.edu

Tarun Ramadorai

University of Oxford

Said Business School

Park End St.

Oxford OX1 1HP

United Kingdom

tarun.ramadorai@sbs.ox.ac.uk

Benjamin Ranish

Department of Economics

Littauer Center

Harvard University

Cambridge, MA 02138

branish@fas.harvard.edu
\end{abstract}

To understand the effects of regulation on mortgage risk, it is instructive to track the history of regulatory changes in a country rather than to rely entirely on cross- country evidence that can be contaminated by unobserved heterogeneity. However, in developed countries with fairly stable systems of financial regulation, it is difficult to track these effects. We employ loan-level data on over a million loans disbursed in India over the 1995 to 2010 period to understand how fast-changing regulation impacted mortgage lending and risk. We use cross-sectional differences in the time- series variation of delinquency rates, conditional on initial interest rates, to detect the effects of regulation on mortgage delinquencies.

An online appendix is available at:

http://www.nber.org/data-appendix/w18394 


\section{Introduction}

How does mortgage regulation influence the structure and performance of housing finance? This paper answers the question by analyzing administrative data on over 1.2 million loans originated by an Indian mortgage provider, relating loan pricing and delinquency rates to the changing details of Indian mortgage regulation.

A more common approach to this question is to compare mortgage systems across countries. Casual observation reveals striking cross-country differences. A recent survey by the International Monetary Fund (IMF 2011) shows that among developed countries, homeownership rates range from $43 \%$ in Germany to about $80 \%$ in southern European countries. The level of mortgage debt in relation to GDP varies from $22 \%$ in Italy to above $100 \%$ in Denmark and the Netherlands. The terms of mortgage instruments are overwhelmingly adjustablerate in southern Europe, and fixed-rate in the United States. Mortgages are funded using a wide variety of mechanisms, including deposit-financed lending, mortgage-backed securities, and covered bonds.

Government involvement in mortgage markets also varies across countries, and it is likely that this explains at least some of the cross-country variation in housing finance. However, it is hard to disentangle regulatory effects from other factors that may affect household mortgage choice across countries, including historical experiences with interest rate and inflation volatility, which can have long-lasting effects because consumers can be slow to adopt new financial instruments (Campbell 2012). An appealing alternative approach is to trace the effects of mortgage regulation over time within a single country rather than rely entirely on cross-country evidence that can be contaminated by unobserved differences across countries. The difficulty in doing this is that developed countries tend to have fairly stable systems of financial regulation, so one rarely has the opportunity to track the effects of sharp regulatory changes. Slow changes, such as those that occurred in the US during the early and mid-2000s, may well be important but it is hard to show this convincingly. For this reason academic writers and public policy commentators have reached no consensus on the degree to which regulation, rather than other factors, caused the US mortgage credit 
boom. ${ }^{1}$

Mortgages are rapidly becoming important financial instruments in emerging markets. Here, financial regulation is at least as intrusive and much less stable. In addition, longlasting historical influences are likely to be less important in emerging markets because their rapid growth and financial evolution reduce consumer inertia. For this reason, emerging markets are ideal laboratories in which to examine the effects of mortgage regulation.

This paper studies the mortgage market in India, a large and complex emerging economy. India has been studied extensively by the economics profession, which has mainly analyzed issues of poverty and development (see, for example, Besley and Burgess, 2000, and Banerjee et al., 2007), or the impact of the Byzantine system of laws and regulations on industrial organization and firm output (see Aghion et al., 2008, and von Lilienfeld-Toal, Mookherjee, and Visaria, 2012 for example). India underwent an economic liberalization in the early 1990s and subsequently experienced rapid economic growth that accelerated further in the 2000s. During this time the financial sector has become much larger and more sophisticated, but remains highly regulated, with a significantly nationalized banking sector.

It is only very recently that authors such as Anagol and Kim (2012) have begun to study India in the context of financial regulation and its impacts on fast-changing Indian capital markets. The provision of housing finance is evolving particularly rapidly (Tiwari and Debata 2008, Verma 2012). Regulatory norms have changed frequently, albeit with a continuing emphasis on funding housing for low-income households. There is increased competition between mortgage lenders, and this may have contributed to rapidly increasing house prices since 2002. Indian mortgages include both fixed and variable rate loans, but there has been a significant shift over time towards the latter.

The challenge in emerging markets, India included, is to find adequate data. Many questions about mortgage finance can only be answered using microeconomic data, either at the household level or the loan level. There is now a vast literature looking at such data

\footnotetext{
${ }^{1}$ A range of views can be found in Acharya, Richardson, van Nieuwerburgh, and White (2011), Baily (2011), Ellis (2008), International Monetary Fund (2011), and US Treasury and Department of Housing and Urban Development (2011), among other sources.
} 
in the US, but it is harder to find in less wealthy countries with rapidly changing financial systems. $^{2}$ We are fortunate to have access to loan-level administrative data from an Indian mortgage provider. We analyze over 1.2 million mortgages disbursed by the mortgage provider between 1995 and 2010, and attempt to understand the determinants of mortgage rate setting and delinquencies.

Our ability to use microeconomic data is important because pure time-series variation in mortgage risk, even if correlated with changing regulation, may also be explained by the changing state of the macroeconomy. Instead, we measure cross-sectional variation in the time-series movements of mortgage delinquency, and link this cross-sectional variation to the incentives created by regulations. One widely used implementation of this approach uses a regression discontinuity design, seeking to identify a discontinuous change in behavior around a threshold created by regulation. However this approach confronts numerous challenges, the most obvious being when regulations do not have clearly identifiable points of discontinuity. Yet another is when regulatory discontinuities lead to changes in the incentives and behaviors of market participants, which in turn serve to blur identification near regulatory boundaries. Both of these issues arise in the Indian context, leading us to pursue an alternate approach. In particular, we link time-variation in regulatory incentives to cross-sectional variation in their expected impacts on different types of mortgages, as well as to geographical variation across local offices operated by the mortgage provider.

Our approach yields two main findings on the relation between regulation and mortgage risk. First, throughout the period of study, small and micro loans are particularly favoured by the Indian regulatory environment. We uncover evidence that the implicit subsidies to such loans show up in a higher propensity for them to default than can be accounted for by their mortgage rates at issuance and all other determinants in the model. This tendency is highly statistically significant, is greater for micro loans than for small loans marginally under the subsidy-qualifying threshold, and is observed in all cohorts of loan

\footnotetext{
${ }^{2}$ Some recent mortgage studies using US microeconomic data include Adelino, Gerardi, and Willen (2009), Agarwal et al (2011), Amromin et al (2011), Bhutta, Dokko, and Shan (2010), Demyanyk and van Hemert (2011), Foote et al (2010), Johnson and Li (2011), Keys et al (2010), Melzer (2011), Mian and Sufi (2009), and Piskorski, Seru, and Vig (2011).
} 
issuance over the sample period. However, finding evidence of a discontinuity at the subsidyqualifying threshold is complicated by the responses of higher-income home-buyers, who have incentives to benefit from these subsidies by taking out small loans just underneath the subsidy-qualifying threshold. These actions, in turn, would result in a blurring of the otherwise expected discontinuity in delinquency rates observed on either side of the threshold.

As a result, we adopt our alternative approach, and connect the magnitude of the excess delinquency propensity of small and micro loans to time-series variation in the tightness of the constraint favoring these loans. The regulator only periodically adjusts the nominal subsidyqualifying threshold. This means that the real value of the constraint on the mortgage provider to make qualifying loans varies over time. We find strong evidence that the excess delinquency propensity of small and micro loans co-varies significantly with this measure of constraint tightness, which we view as evidence of the impacts of regulation on mortgage risk. We also document that there is important geographical variation in delinquency rates, which operates in a fashion consistent with a strategic response of the mortgage provider to the regulatory incentives which it faces.

The second important change that we track in the Indian regulatory environment occurs in March 2004. At this point, the regulatory definition of "non-performing assets," changes from previously referring to loans that are six-months delinquent to those that are threemonths delinquent. Since provisioning requirements against delinquencies are tied to this definition, we expect that this change creates incentives for the mortgage provider to monitor loans earlier, and potentially to improve loan screening. To investigate, we track loans as soon as they are flagged as delinquent, which is when they are one-month behind on payments. Following the regulatory change, we find that these one-month delinquent loans are far less likely to subsequently become three-months delinquent. Furthermore, using a subsample of 10,000 loans for which we have a complete time-series of payment histories, we uncover evidence that is consistent with greater effort on the part of the mortgage provider to monitor delinquencies in response to this regulatory change. In particular, we find that debt collection rates on one-month delinquent loans are accelerated in the interval before 
they hit the new three-month mark for classification as a non-performing asset. Importantly, perhaps as a result of incentivizing mortgage lenders to act early on delinquent loans, we find that this change substantially lowers the likelihood of experiencing longer-term defaults. This impact on long-term defaults is even larger than that arising from a 2002 legal change in the ability of mortgage providers to more easily repossess or restructure non-performing assets. Moreover, we identify that the primary impact of the regulation is on improved ex-post monitoring rather than on better ex-ante screening.

Taken together, these two findings provide compelling evidence that regulatory norms impact the risk of delinquencies experienced by our Indian mortgage provider on loans issued. Our evidence complements recent findings using U.S. data on the impacts of regulatory norms on mortgage screening (Keys et al. 2011), and is also related to work on how mortgage credit expansion in the U.S., particularly in sub-prime zipcodes, contributed to the recent crisis (Mian and Sufi 2009). Our evidence on the role played by subsidies in the increased delinquency rates on small loans contributes to the debate on whether such subsidies in other countries, such as the U.S. Community Reinvestment Act (CRA), had similar effects (see, for example, Dahl, Evanoff, and Spivey 2000, Kroszner 2008, and Agarwal, Benmelech, Bergman, and Seru 2012). Finally, our model shows that controlling for a range of determinants of mortgage risk, the time when a loan is issued has significant explanatory power, a finding related to the analysis of Demyanyk and van Hemert (2011) who perform a similar analysis to explain U.S. sub-prime mortgage risk.

The organization of the paper is as follows. Section 2 sets the stage by describing the Indian macroeconomic environment and the Indian system of mortgage regulation during the quarter century since 1985, together with the mortgage data we employ. Further details Indian mortgage regulation are provided in an online regulatory appendix (Campbell, Ramadorai, and Balasubramaniam 2012). Section 3 introduces our model of mortgage delinquencies, which we use to explore the effects of regulation on the relative delinquency rates of different types of loans. Section 4 discusses the change in the regulatory definition of non-performing assets in 2004 and its consequences on observed delinquency and repayment patterns. Section 5 concludes. Additional empirical evidence on the Indian mortgage market 
is reported in an online empirical appendix (Campbell, Ramadorai, and Ranish 2012).

\section{The Macroeconomic and Regulatory Environment}

\subsection{Macroeconomic Trends}

To set the stage, Table 1 summarizes the history of several important Indian macroeconomic variables over the quarter-century from 1985-2010, including annual real GDP growth, CPI inflation, and government bond yields. Regulatory and macroeconomic reform in the early 1990s was followed by growth in the 4-8\% range until the early 2000 s, when growth accelerated above $8 \%$, briefly slowed again only by the global financial crisis in 2008. Meanwhile inflation was high and volatile during the 1990s, with volatility particularly elevated around the reform period and in 1998-99. A period of more stable inflation followed in the 2000s, but inflation accelerated at the very end of our sample period.

Indian government bond yields over the same period are also quite volatile. The 1-year yield declines from double-digit levels in the mid-1990s, with considerable volatility in the late 1990s related to the volatile inflation experienced at the same time. After a low of about $5 \%$ in the early 2000s, the 1-year yield spikes up in 2008, again related to concerns about inflation. The 10-year yield is smoother but also undergoes a large decline from the mid-1990s until the early 2000s.

Figure 1 plots real house price indexes, both for India as a whole and for five broad regions. The real rate of house price appreciation for the country as a whole is also reported in Table 1. We compute these indexes using the mortgage provider's own property cost data, but data from the National Housing Bank (NHB) show similar patterns. Indian house prices were relatively stable until the early 2000s and then began to increase rapidly, particularly in the south of the country. The southern index peaks in 2008 while some other regions peak in 2009. Thus India took part in the worldwide housing boom despite many differences in other aspects of its macroeconomic performance.

These house price movements are important for our study because they interact with 
government policies favoring smaller loans. As house prices increase, fewer loans naturally qualify for favorable regulatory treatment, creating time-series variation in the tightness of regulatory constraints on mortgage lending. Understanding this effect requires a detailed explanation of the Indian regulatory system, which we now provide.

\subsection{The Regulatory Environment}

Mortgages in India are originated by two types of financial institutions, banks and housing finance companies (HFCs). Banks are regulated by the Reserve Bank of India (RBI), while housing finance companies are regulated by the National Housing Bank (NHB), but most regulations apply in fairly similar form to the two types of institution. This fact is important for our study, as we are unable to publicly identify whether our mortgage provider is a bank or an HFC.

Figure 2 summarizes the details of mortgage regulation in India in a relatively parsimonious fashion. The top half of the figure shows regulations that applied to banks, and the bottom half to HFCs. The regulations that remained constant throughout the period are listed in black, whereas the ones that changed over the period are in colored font. In light of the significant changes that took place from 2001 to 2002, we separate the timeline into the "first period," i.e. prior to March 2001, and the "second period" which extends from April 2001 until the end of the sample period. In the middle of the figure, we summarize subsidy schemes for micro-lending with the length of the bars accompanying these schemes identifying their start and end dates relative to the timeline.

Regulations can be divided into two types: those that restrict the funding of mortgage lending, and those that incentivize lending to favored borrowers. Until 2001, mortgage funding was regulated in a fairly traditional manner, using leverage restrictions on banks and HFCs, and interest-rate ceilings on deposit-taking HFCs. From 2002 onwards, these measures were augmented by capital requirements against risk-weighted assets following the internationally standard Basel II framework. The RBI and NHB distinguished small and large loans, and loan-to-value (LTV) ratios above and below 75\%, and set different risk 
weights for these different categories with frequent changes for loans below $75 \%$ LTV. In this way the regulators shifted the risk capital available to banks and HFCs, and the incentives for aggressive mortgage origination.

Another noteworthy change in the regulatory environment is highlighted on the timeline, and occurred on March 31, 2004 for banks, and one year later, i.e., March 31, 2005 for HFCs. At this time the RBI redefined an asset as a "non-performing asset" (or NPA) if payments (on interest or principal) remained overdue for a period of ninety days or more, from the previous 180 day period allowed before assets were so classified. One important implication of the classification of an asset as an NPA is that it incurs provisioning requirements, meaning that the capital available to a mortgage lender holding such an asset reduces as the lender is required to hold precautionary capital to cover expected losses.

Related to this NPA redefinition, an important law which came into force somewhat earlier (in July 2002), was the Securitisation and Reconstruction of Financial Assets and Enforcement of Security Interest (SARFAESI) Act. This law enabled the easier recovery of NPAs via securitization, reconstruction, or direct repossession, bypassing the need for secured creditors to seek permission from debt recovery tribunals (see von Lilienfeld-Toal, Mookherjee, and Visaria, 2012, for evidence of the impacts of the establishment of these tribunals in 1993). In our analysis, we separately evaluate the impact of these two changes, namely the redefinition of NPAs in 2004, and the introduction of SARFAESI in 2002, on delinquencies experienced by the mortgage provider.

Lending to small borrowers is an important political goal in India. Banks are subject to a quantity target for Priority-Sector Lending (PSL), which includes loans to agriculture, small businesses, export credit, affirmative action lending, educational loans, and - of particular interest to us - mortgages for low-cost housing. The PSL target is $40 \%$ of net bank credit for domestic banks ( $32 \%$ for foreign banks), and there is a severe financial penalty for failure to meet the target, namely, compulsory lending to rural agriculture at a haircut to the repo rate. This regulation does not directly apply to HFCs, but bank lending to an HFC qualifies for the PSL target to the extent that the HFC makes mortgage loans that qualify, i.e., are below the specified nominal PSL threshold. The overall effect of the PSL system is to provide 
an incentive, directly for banks, and indirectly for HFCs, to originate small mortgages that finance low-cost housing purchases.

In addition to the PSL system, other schemes have been introduced at various points in time over the sample period to subsidize new or refinanced micro-lending - i.e., loans of sizes well below the PSL-qualifying threshold. The mid-section of Figure 4 shows the various schemes that were in place to incentivize mortgage lending in very small loan sizes. These schemes apply to both banks and HFCs. Most recently, interest rate subventions have been put in place for the first year of repayments on small loans, payments that are passed through to the borrower in the form of a reduced interest rate, for housing loans up to a maximum size. Special subsidy and refinancing schemes in place for very small rural loans (the Golden Jubilee Rural Housing Finance Scheme or GJRHFS, and the Indira Awas Yojana) and for borrowers qualifying for affirmative action (the Differential Rate of Interest scheme) are also shown in the figure, over the period for which they applied. Taken together, these schemes increase the subsidy for tiny loans over and above the standard subsidy to PSL-qualifying loans.

As is evident from the brief description above, it is not a trivial task to document the changes in the system of Indian mortgage regulation as these have been frequent, and are not summarized in any one place. The online regulatory appendix to this paper, Campbell, Ramadorai, and Balasubramaniam (2012), provides further details about the regulatory system, and serves as a comprehensive guide to Indian mortgage regulation over the period of our study.

\subsection{Evolution of the Mortgage Market}

Both macroeconomic and regulatory forces have contributed to rapid change in the Indian mortgage market. Table 2 illustrates the changes in three relevant characteristics of mortgages issued by our lender: the shares of variable-rate mortgages, small PSL-qualifying loans, and mortgages with high loan-cost ratios above $75 \%$. The first two columns of Table 2, Panel A show the variable-rate share in the number and value of mortgages disbursed. There has 
been a dramatic shift in the Indian mortgage system away from fixed-rate and towards variable-rate mortgages, with one brief interruption in 2004. Our lender made very few fixed-rate mortgages after 2007. During the period of transition through 2002, variable-rate mortgages were somewhat larger on average than fixed-rate mortgages, as shown by their higher share of value in the second column of the table.

The remaining columns of Panel A show the share of mortgages that are below the PSL threshold, and above $75 \%$ loan-cost ratio, separately for variable-rate and fixed-rate mortgages. The share below the PSL threshold peaks in 2001 (for variable-rate mortgages) and 2000 (for fixed-rate mortgages), and then declines precipitously during the 2000s. The PSL-qualifying share is somewhat higher for fixed-rate mortgages, reflecting their smaller average size. The share of mortgages with loan-cost ratio above $75 \%$ trends upwards, increasing particularly rapidly in the early 2000s (for variable-rate mortgages) and late 1990s (for fixed-rate mortgages).

Both these trends are driven in part by the increase in house prices during the mid-1990s and mid-2000s, shown earlier in Table 1 and Figure 1. Figure 3 illustrates this point in a different way. The solid line in the figure is the unqualified lending share, the fraction of mortgages disbursed that are above the PSL threshold and thus do not qualify for the PSL target. This fraction rises as house prices increase, particularly in the mid-1990s and mid-2000s, but falls discontinuously when the PSL threshold is adjusted. Later in the paper, we use the unqualified lending share as a proxy for the tightness of the regulatory constraint favoring small loans.

Figure 3 also reports the intensity of regulatory preference for loans with loan-cost ratio below $75 \%$. This is measured as the difference in risk weights for loans above and below the $75 \%$ loan-value threshold. It is zero until January 2002, when it rises rapidly to a maximum of 0.5 by the middle of 2003 .

Our data display not only time-series variation in the fractions of loans below the PSL threshold and above $75 \%$ loan-cost ratio, but also geographical variation, which arises naturally from variation in local housing market conditions. Panel B of Table 2 reports the cross-sectional mean, standard deviation, minimum, and maximum fractions of PSL-qualified 
and high loan-cost mortgages, calculated across local offices of our mortgage lender. The cross-sectional (across local offices) standard deviations are 19\% for PSL-qualified loans and $11 \%$ for high loan-cost mortgages. In the empirical work of the next section we exploit this variation to try to detect geographical variation in the mortgage lender's responses to regulatory pressures.

Table 3 presents more details on cohorts of loans issued in each year. Panel A reports cross-sectional cohort means of mortgage terms and delinquency rates. Initial interest rates on variable-rate and fixed-rate mortgages track one another very closely until 2002, and are both close to the Indian prime rate shown in Table 1, despite some variation in the spread between long-term and short-term government yields. In the period 2003-06, the variable mortgage rate is well above the fixed rate and has an unusually high spread over the 1-year bond yield, a feature shared with the Indian prime rate. This period has a generally high market share for variable mortgages, but does include an episode in 2004 when our mortgage lender shifted back towards fixed mortgage issuance. Variable mortgage rates decline after 2008, a period where our lender made few fixed-rate mortgages.

Panel A also summarizes cohort means of loan maturity, loan-cost ratios, and loanincome ratios. The previously discussed increase in loan-cost ratios is visible here too, but loan maturity and loan-income ratios are much more stable. This pattern contrasts with mortgage trends during the 2000s in the US, where loan-income ratios increased while loan-value ratios were relatively stable (Campbell and Cocco 2012).

The right-hand column reports the cohort 90-day delinquency rate, the annual probability that an outstanding and not-yet-delinquent loan experiences a 90-day delinquency, calculated separately for each disbursal-year cohort and calendar year, and then averaged over calendar years for each cohort. The early 2000s appear unusual in the sense that the cohort default rate for mortgages disbursed in these years is high relative to the other cohorts in the sample period, despite loan characteristics such as loan-to-cost and loan-to-income ratios not changing much on average. The 2004 fixed-rate cohort, however, appears to have a significantly reduced default rate.

Figure 4 summarizes the history of Indian mortgage delinquency in a simpler way. It 
plots the overall delinquency rate (the fraction of all outstanding mortgages, regardless of the date of issue, that are 90 days past due), seasonally adjusted using a regression on monthly dummies, for both fixed-rate mortgages (solid line) and variable-rate mortgages (dashed line). The main feature of this figure is the large spike in delinquencies in 2002-03, particularly for fixed-rate mortgages. Delinquencies decline to quite low levels by 2005, and remain low to the end of our sample period despite the weak housing market in 2009-10.

Panel B of Table 3 shows the cross-sectional standard deviation of loan characteristics and initial interest rates. In the early 2000s there is a large spike in the cross-sectional dispersion of variable mortgage rates. This spike coincides with the period of increased delinquencies documented earlier, and may reflect increased efforts by our mortgage lender to distinguish among borrowers by estimating their default risk and setting mortgage rates accordingly. For fixed mortgage rates, while the same pattern is not evident in the crosssectional dispersion of initial interest rates, there does seem to be an increase in the early 2000s in the cross-sectional dispersion of loan-to-cost ratios, which reduces again in 2004.

In the remainder of this paper, we explore in more detail the relation between mortgage regulation and these movements in mortgage delinquencies.

\section{A Model of Mortgage Delinquencies}

In this section we attempt to shed light on the factors which contributed to changes in the mortgage delinquency rate over time and across cohorts, paying special attention to the changing regulations described in the previous section. In order to do so, we propose and estimate a model of mortgage delinquencies, recognizing that their determinants include demographic characteristics of borrowers, measurable characteristics of loans, cohort-specific variation, and (imperfectly observable) variation in macroeconomic conditions.

In our baseline specification, we model the probability of observing a delinquency as a function of all of these determinants:

$$
\operatorname{Pr}\left[\delta_{i, c, b, r, t}\right]=\left(\alpha+\alpha_{r}+\alpha_{c}+\alpha_{b}+\Sigma_{k} \beta_{r k} L_{i k t}+\Sigma_{j}{ }_{j} D_{i j t}+\rho_{r} r_{i}\right) Z_{r, t \square 1}+e_{i, t}^{\delta},
$$


where $\delta_{i, c, b, r, t}$ is an indicator for an observed 90-day delinquency in loan $i$ with interest-rate type $r$ (fixed or variable) in cohort $c$ originated in branch $b$, at time $t$. That is, $c$ denotes the loan origination date and $t$ denotes the observation date. The model includes fixed effects for each interest rate type, $\alpha_{r}$, branch $\alpha_{b}$, and cohorts, $\alpha_{c}$. In each case, we drop one dummy as we have an intercept in the model. The model also includes loan characteristics $L_{i k t}$ indexed by $k$, and demographic characteristics $D_{i j t}$ indexed by $j$, for each borrower $i$. These characteristics can potentially vary over time, although in practice most of the ones we measure are constant over time. The initial interest rate on the mortgage, $r_{i}$ is also included as an explanatory variable in the model. ${ }^{3}$ The coefficient on initial interest rate and on loan term (in the set of loan characteristics $L$ ) have a subscript $r$ to indicate that separate coefficients are allowed here for fixed and variable rate mortgages; loan term and initial interest rate do not necessarily relate to risk in the same way for fixed and variable rate mortgages. In the subsequent sections, we augment this basic specification to include timeseries variation in regulatory thresholds, interacted with dummies to capture cross-sectional variation in the expected impacts of these changes.

The model allows for an unobserved macroeconomic shock $Z_{r, t \square 1}$ to impact these determinants multiplicatively, and we allow a separate set of shocks to affect fixed and variable rate mortgages. While in practice the time-series of estimated fixed and variable rate shocks appear quite similar, this flexibility is important, since the macroeconomic shocks that drive delinquency may be different if mortgage rates adjust to interest rate movements (Campbell and Cocco 2012).

Given the presence of macroeconomic shocks, the estimated coefficients on the branch and cohort fixed effects, and loan and demographic characteristics show the extent to which these factors alter the propensity for a loan to default as macro conditions vary. To fix ideas, consider a high estimated value of a particular cohort effect - this would indicate a high propensity of loans in that cohort to default when times are bad, i.e., when $Z_{r, t \square 1}$ is high.

\footnotetext{
${ }^{3}$ The model is estimated at the annual frequency $t$; to eliminate monthly seasonal variation, we de-mean all left- and right-hand side variables at the monthly frequency and add back the annual mean. This change is innocuous, having little impact on our results.
} 
The choice of $Z_{r, t \square 1}$ rather than $Z_{r t}$ as the macroeconomic shock influencing delinquency at time $t$ captures the fact that 90-day delinquencies are not realized contemporaneously with deteriorations in macroeconomic circumstances. Rather, we expect to see delinquencies materialize some period of time after negative macroeconomic shocks, as delinquencies result from borrower-level cash-flow problems, which likely occur with a lag.

We employ a two-stage estimation procedure, in which the first stage comprises $T$ crosssectional regressions estimated across all loans outstanding, and not yet delinquent, in each year $t \in T$. In the second stage, we employ the classical minimum distance estimator (see, for example, Wooldridge 2002) to extract estimates of $Z_{t}$ and the static parameters of the model. As a check on our procedure, we confirm that two-stage estimation produces estimates that are very close to those obtained via single-step estimation using non-linear least squares. To obtain standard errors for the second stage estimates we use a crosssectional correlation consistent bootstrap procedure, in which we draw a set of time periods equal to the total number of years (15) in our data $t_{b}^{1}, \ldots, t_{b}^{15} \in T$ with replacement, and assemble a simulated dataset for each bootstrap draw $b$. We then re-run the second stage regressions for $b=500$ draws.

Figure 5 plots a weighted average of the estimated macroeconomic shocks for fixed and variable rate mortgages, $Z_{r t}$. The figure also shows two different measures of macroeconomic conditions: real GDP growth, and the average real rate of growth in corporate sales, firm fixed assets, and firm net worth estimated from the population of Indian firms available in the Prowess database. ${ }^{4}$ The figure, in which all series are standardized for ease of comparison, shows that estimated $Z_{r t}$ seem closely, although not perfectly related to these other measures. All three measures indicate that 2002 and 2003 were periods of particularly poor macroeconomic conditions, with a complete recovery in the Indian macro environment only by 2005. Thus our model explains the spike in delinquencies in 2002-03, illustrated in Figure 4, by macroeconomic shocks occurring at that time.

\footnotetext{
${ }^{4}$ This database comprises the population of listed and large unlisted Indian firms, and is considered to be the main source of information on Indian corporates (see, for example, von Lilienfeld-Toal, Mookherjee, and Visaria, 2012).
} 


\subsection{Household- and Loan-Level Determinants of Delinquency}

The demographic variables that we employ include the borrower's gender, marital status, number of dependents, and dummies for age (up to age 35, 36-45, and 46 and above), for education (high-school measured by higher-secondary certificate or HSC, college, postgraduate, and missing), for a finance-related educational qualification, and for a repeat borrower. The loan characteristics include the loan-to-cost ratio, log loan amount, log loan-to-income ratio, and dummies for whether the loan was paid by salary deduction or via a special scheme with the employer, as well as dummies for special loan characteristics (tranched issuances and refinancings), specific loan purposes (home extension or improvement), and mortgage contract terms (loan maturities 6-10 years, 11-15 years, or 16 years and above, estimated separately for fixed and variable-rate mortgages). We also include a dummy for mortgages observed in the first year of issuance.

To control for house-price movements, we also include in the set of loan characteristics regional house-price appreciation up to time $t$ from the time of the disbursal of the loan. For variable-rate loans only, we control for the change in the 1-year Indian government bond yield since issuance. Finally, we include a dummy variable which takes the value of 1 if a loan is disbursed from a branch in the 12 months prior to a state election, to capture the possibility (documented by Cole 2009 for Indian agricultural lending) that in election seasons there may be pressure to disburse politically expedient loans, which have a higher propensity to be delinquent.

Table 4 reports the estimated coefficients on these demographic and loan characteristics. These are typically statistically significant, with the theoretically expected sign. Older male and repeat borrowers have a higher delinquency rate, while more educated borrowers have a lower rate. Interestingly, however, a finance-related educational qualification slightly increases the delinquency rate, possibly because financial-sector income is more volatile. Mortgages with higher loan-income and loan-cost ratios are more likely to become delinquent, but the absolute size of a loan lowers the delinquency rate. Loans paid through salary deduction or administered through employers have lower delinquency rates. Loans with 
long maturity have higher delinquency rates, as do fixed-rate mortgages. The latter result may be related to the generally downward trend of interest rates during this period in India, although our variable that measures the change in the Indian one-year government bond rate since issuance (for variable-rate mortgages only) does not enter the regression significantly. Regional house prices have a powerful effect on delinquency, as one would expect, but we do not find any evidence that loans disbursed in election seasons are unusually likely to become delinquent.

All of these variables are significant in the presence of the initial mortgage interest rate, which however enters the regression significantly as well. This implies that the mortgage lender does have information relevant for predicting delinquency, and uses it to set rates, but does not fully adjust the initial mortgage rate to the probability of delinquency conditional on observable borrower and loan characteristics.

\subsection{Regulation and Delinquencies: PSL Norms}

In order to assess the impact of regulation on delinquencies, we next include regulatory variables in our regression along with the demographic and loan characteristics. Table 5 reports the results. The top part of the table reports variables related to PSL norms, while the bottom part looks at the effect of risk weights on mortgages with high loan-cost ratios.

Table 5 includes three specifications, labeled A, B, and C. Specification A includes a piecewise linear function of log loan size, with a kink at the PSL threshold. In addition, the slope below the PSL threshold is interacted with the unqualified lending share, which as previously discussed we use as a proxy for the intensity of regulatory pressure to originate small loans. When the unqualified lending share is high, house prices are high relative to the PSL threshold and the mortgage lender is particularly keen to originate PSL-qualifying loans which are in short supply. Consistent with this view, we find that delinquency rates increase as loan sizes get smaller, but the effect is statistically significant only below the PSL threshold, and the slope of this relationship gets steeper when the unqualified lending share is high. 
Figure 6 summarizes this result graphically. The top panel of the figure shows the variation in the delinquency rate associated with log loan size relative to the PSL threshold. Above the threshold, there is almost no effect, but the smallest loans have a delinquency rate that is $1.5 \%$ higher when the unqualified lending share is one standard deviation below its mean, and over $2 \%$ higher when the unqualified lending share is one standard deviation above its mean.

Specification B considers geographic variation in delinquency rates and PSL-qualified lending. This specification retains the variables from specification $\mathrm{A}$, which continue to have very similar estimated coefficients, but adds three new variables. The first is the unqualified lending share in the sub-branch originating each loan. This has a negative coefficient, consistent with the view that loans originated in wealthy areas (where PSL-qualifying loans are relatively scarce) are safer than loans originated in poor areas. Then, the subbranch-specific unqualified lending share is demeaned in each cohort (to avoid contaminating the interpretation of the coefficients we have discussed so far), and interacted with both loan size below the PSL threshold, and the interaction of this variable with the overall unqualified lending share (creating a triple interaction). Both these interactions are statistically significant and negative. This tells us, first, that the spread in delinquency rates between poor and wealthy areas is narrower for smaller loans, and second, that the narrowing of the delinquency spread for small loans is stronger when there is more intense regulatory pressure to originate small loans. Putting these effects together, the mortgage lender appears to respond to regulatory incentives to originate small loans by increasing risky small lending particularly in sub-branches that do relatively little PSL-qualifying lending. Such a reaction may be rational given the overall lower risk of loans originated in these sub-branches.

The bottom panel of Figure 6 illustrates this result by plotting the spread in delinquency rates between a sub-branch with an unqualified lending share one standard deviation below the mean, and a sub-branch with an unqualified lending share one standard deviation above the mean. The spread narrows as loan size declines, but this narrowing is negligible when the overall unqualified lending share is one standard deviation below the mean, and substantial (about 50 basis points for loans two standard deviations smaller than the PSL threshold) 
when the overall unqualified lending share is one standard deviation above the mean.

The final specification in Table 5, specification $\mathrm{C}$, shows that the time-series and crosssectional effects on mortgage risk, discussed above, can be summarized using a single variable interacted with loan size, the sub-branch-specific unqualified lending share. In other words, the pattern of mortgage risk in our data is similar to what we would expect if each subbranch of the mortgage lender were an independent entity responding to regulatory pressure summarized by the sub-branch's own unqualified lending share.

The patterns in mortgage risk shown in Table 5 suggest that the mortgage lender responds to regulatory pressure by increasing the volume of PSL-qualifying loans. Table 6 reports some more direct evidence that this is the case. Panel A of the table looks at four changes in the PSL threshold, and records growth rates of mortgage lending within narrow bands of loan size (either $1 \%$ or $2.5 \%$ ) around the old and new thresholds. Since the old threshold becomes irrelevant for PSL-qualifying lending, while the new threshold becomes relevant, one would expect regulatory pressure to increase lending immediately above the old threshold relative to lending immediately below, and to increase lending immediately below the new threshold relative to lending immediately above. Panel A of Table 6 reports the average of lending growth above minus below the old threshold, and below minus above the new threshold, within one year of the threshold change. The estimated effect is large, at $41 \%$ for a $1 \%$ band and $30 \%$ for a $2.5 \%$ band, although it also has a large standard error.

Panel B of Table 6 looks at geographical variation in the volume of PSL-qualifying lending. We estimate a regression predicting the change in log share of sub-branch lending below last month's PSL threshold, using the lagged sub-branch PSL share, a dummy for a PSL threshold change, and the dummy interacted with the lagged sub-branch PSL share. An increase in the threshold lowers the propensity to make loans below the old threshold, and this effect is stronger in sub-branches with low PSL shares, that is in sub-branches in wealthy areas. The interaction effect has the sign we would expect given the results of Table 5 , although it is not statistically significant. 


\subsection{Regulation and Delinquencies: Risk Weights}

We also use our regression (1) to examine the effect of changing risk weights for mortgage loans with high loan-cost ratios. The bottom part of Table 5 predicts delinquencies using a piecewise linear function of the loan-cost ratio, with kinks at $65 \%$ and $85 \%$. The slope in the intermediate range between $65 \%$ and $85 \%$, which is most affected by risk weights, is interacted with the difference in risk weights between loans above and below a $75 \%$ loanto-value ratio. As the mortgage provider reports only the similar loan-to-cost ratio, the inflection points at loan-to-cost ratios of $65 \%$ and $85 \%$ are equivalent to an assumption that loan-to-cost ratios above $85 \%$ are always above $75 \%$ loan-to-value, and conversely for loans below loan-to-cost ratios of $65 \%$.

The results of this exercise are not much affected by the choice of specification $\mathrm{A}, \mathrm{B}$, or C. In all cases the effect of the loan-cost ratio on delinquency is strongest in the intermediate range. This is consistent with the view that extremely low loan-cost ratios have little impact on loan risk (since the loan is extremely well collateralized already), while extremely high loan-cost ratios are unusual loans that are only made in special circumstances to particularly high-quality borrowers. The interaction effect is negative, implying that

high risk weights for mortgages with high loan-cost ratios tend to reduce delinquency rates for these mortgages relative to loans with lower loan-cost ratios. However, the interaction effect is not statistically significant. Figure 7 illustrates the result graphically for the case of specification A.

Despite not being greatly statistically significant, our findings here are consonant with the suggestion of Kashyap, Rajan, and Stein (2008) that capital requirements against riskweighted assets should be countercyclically adjusted. Reductions in the risk-weight on housing finance in our time-series follow a period of low GDP growth, and are associated with higher levels of mortgage delinquencies for high loan-cost ratio loans issued in those cohorts. This suggests that Kashyap, Rajan, and Stein's policy can influence the riskiness of mortgage lending. 


\section{Impact of the Regulatory Classification of Non-Performing}

\section{Assets}

In this section we examine another regulatory change that took place during our sample period. On March 31, 2004 for banks, and March 31, 2005 for HFCs, the classification of "non-performing assets" (or NPAs) was changed to 90 days past due from the previous time period of 180 days past due. This regulatory reclassification of 90-day delinquencies, and its implications for provisioning requirements, may have contributed to the unusually low 90-day delinquency rates reported in Table 3 for more recent loan cohorts. One mechanism by which this might occur is that the reclassification may have given our mortgage lender the incentive to more intensively monitor shorter-term delinquencies (say 30 days past due), and to take earlier action to forestall 90-day delinquency. As described earlier, we do not take a firm stand on the exact month of delinquency in which there might be a discontinuity, but rather, track loans before and after the regulatory change, across their time-path of delinquency.

We therefore evaluate the expected loss given a delinquency before and after the regulatory reclassification. This expected loss is the product of the probability of experiencing a delinquency and the loss given delinquency. Table 7 looks at the first of these two elements, computing transition probabilities of loans that hit the 30-day delinquency threshold to the 90-day delinquency mark, as well as the transition probability of 90-day delinquencies to the 180-day delinquent mark. The table shows that across the entire sample period, $22.7 \%(22.8 \%)$ of 30 -day (90-day) delinquent loans eventually become 90 days (180 days) delinquent.

As we are unable to publicly identify whether the mortgage provider is a bank or an HFC, we use the earlier RBI implementation date of 31 March 2004 as the date of the regulatory change, to cover all possibilities. When we look separately at the pre-April 2004 period for the 30-day delinquencies, the transition probability is $29 \%$, which is almost twice as high as the post-March 2004 transition probability of $14.9 \%$, and the reduction, of $14.1 \%$ is highly statistically significant. Clearly, following the change in the definition of NPAs to the 
shorter 90-day limit, the mortgage provider substantially reduced this transition probability, potentially by exerting effort to pursue borrowers more aggressively. The 90-day to 180-day transition probability also reduces following the 2004 reclassification, but by a much smaller $2.3 \%$, suggesting that once the loan becomes classified as an NPA, there are relatively fewer incentives to take action. Another possibility, of course, is that the loans reaching the 90-day delinquency mark are simply very difficult to collect on despite the lender's exertions. ${ }^{5}$

To better understand the magnitude of loss given delinquency, we acquire a sample of 10,000 loans from the total population of loans. As our focus is to understand the determinants of mortgage risk, we randomly sample 2,500 fixed-rate and 2,500 variablerate loans from the set of 90-day delinquent loans, and a further 2,500 fixed-rate and 2,500 variable-rate loans from the set of loans that do not experience a 90-day delinquency. In each sub-sample of 2,500 loans, we further ensure that we sample an equal number $(1,250)$ from the early period in the data (disbursed prior to January 2000) and the later period (disbursed between January 2000 and December 2004). We have verified that this 10,000 loan sample has statistically indistinguishable characteristics from the population of loans from which we draw. For each one of these 10,000 loans, we are able to track the full payment history over time, as well as deviations from contracted repayments. We can compute the latter as we are also given the equated monthly installment (EMI) for each of these loans in each month, which is the expected monthly principal repayment plus interest amount. We ensure that we weight any measures constructed using this sample, so that they are reflective of the larger population of loans from which the sampling occurred.

For each loan in the sample, we construct a measure of losses accrued over time. To do so, we accumulate payments and EMI over time, and compute the "cumulative installment deficit" (or CID) as Min(0, cumulative payment-cumulative EMI)/EMI. This measure takes the value of zero if monthly payments exceed or equal the EMI, and is negative otherwise,

\footnotetext{
${ }^{5}$ It is also worth noting here that the 2002 implementation of SARFAESI, described above, allowed for easier restructuring and repossession of delinquent loans. However the small change in the 90-180 day transition probability despite this regulatory change mirrors the insignificant post-SARFAESI change in the $\Delta$ CID debt collection rate that we define and analyze below. These results suggest that at least for housing loans, this particular regulatory change may not have had very large effects.
} 
indicating when borrowers are in arrears. The cumulation ensures that if overpayments are made to redress arrears, these are allowed to push the measure towards zero. The division by EMI puts the cumulative installment deficit into units of required monthly payments.

Figure 8 plots the CID measure around 30-day delinquencies, before and after the regulatory change to the definition of NPAs. The measure is cross-sectionally demeaned by both cohort-year and calendar-year, to ensure that we are not picking up cohort or macroeconomic effects. In both panels of Figure 8, date 0 is the first date that the loan is declared 30-days delinquent (values below 1 are possible because of the cross-sectional demeaning). The top panel shows that prior to the change in the regulatory definition of NPAs, loans declared 30-days delinquent on average inflicted a cost on the mortgage provider of roughly 1.1 EMIs after a year. Post-March 2004, there is a substantial recovery in this number, with such 30-delinquent loans roughly 0.3 EMIs delinquent 12 months later. The bottom panel of the figure shows that this change in the behavior of the CID after the regulatory redefinition of NPAs is highly statistically significant.

We undertake this analysis more formally by estimating how changes in the CID vary following a 30-day delinquency, but prior to hitting the 90-day threshold, both before and after the regulatory redefinition of the NPA period. To do so, we estimate expected debt collection rates - changes in the CID - as a polynomial function of the level of the CID prior to the 90-day delinquency mark (i.e., a CID level of $\square 3$ ), allowing for a jump in the rate at the 90-day delinquency mark, and modelled as a linear function of the CID beyond the 90-day delinquency mark. As before, we include time- and cohort-specific fixed effects during estimation to ensure that we are not merely picking up some of the broader changes detected earlier in the regulatory and macroeconomic environment.

Figure 9 shows how the estimated debt collection rate varies before and after the 90day delinquency threshold, before and after the regulatory redefinition of NPAs in March 2004. The figure clearly reveals that following the regulatory redefinition of NPAs, the debt collection rate prior to hitting the 90-day mark increased substantially relative to the preregulatory change period, with a significant discontinuity at the 90-day threshold, where the 
debt collection rate falls sharply. ${ }^{6}$ We also consider whether the introduction of SARFAESI had any significant impacts on the ability to collect on debts, and find that while there is a mild increase in the pre-90 day debt collection rate, it is dwarfed by the change following the NPA redefinition (moreover, the small discontinuity evident in this line at the 90-day mark is statistically insignificant).

While these changes to debt collection rates are clearly evident in the data, one potential worry is that the redefinition of NPAs from 180 to 90 days simply shifted the inevitable recovery of cash from delinquent borrowers by the 90-day difference between these two dates. In other words, perhaps the change merely provided a time-value improvement in the net cash flows of the mortgage provider, but no more substantial impacts.

To address this question, Figure 10 shows the cumulative distribution function (CDF) of the change in the CID (time- and cohort-demeaned) in the year following the first 30 day delinquency. This CDF is plotted for three time periods, namely, January 1995 to June 2002, when SARFAESI was first implemented; July 2002 to March 2004, the date of the redefinition of NPAs; and post-April 2004 until the end of the sample period in 2010. We plot the figure on a log scale to focus attention on the very worst cases (i.e., those loans with the greatest degradation in CID over the year following the date of first 30-day delinquency), as these loans are the most likely candidates for a complete write-off.

The figure shows that the post-NPA redefinition CDF first-order stochastically dominates both the pre- and post-SARFAESI CDFs, showing a substantial reduction in the incidence of high degradation in the CID. While SARFAESI appears to have had some beneficial impacts for the very worst cases, this is dwarfed by the large impact of the NPA redefinition. These substantial impacts on eventual bad debts of this regulatory redefinition are striking, as it appears that there are important real benefits to incentivizing mortgage providers to detect and take early action on delinquencies.

Finally, in Figure 11 we document some evidence that the change in the regulatory

\footnotetext{
${ }^{6}$ The increase in the debt collection rate prior to the 90-day delinquency mark, and the discontinuity at that mark are both economically and statistically significant. The online empirical appendix plots the difference between the pre- and post- NPA redefinition debt collection rates with associated bootstrap confidence intervals.
} 
classification of NPAs affected mortgage origination as well as mortgage monitoring practices. This figure reports the same curve as in Figure 10, separately for loans originated in a six-month window before the NPA reclassification and in a six-month window after the reclassification. The left tail of the distribution is noticeably thicker for loans originated before the reclassification, even though both cohorts of loans are experiencing delinquency after the reclassification and hence are subject to post-reclassification monitoring by the mortgage lender. This implies that the reclassification induced the mortgage lender to tighten mortgage origination standards slightly as well as to monitor mortgages more closely.

In summary, a simple change in the regulatory definition of NPAs appears to have significantly moderated mortgage delinquencies. The impacts are visible in both the probability of delinquency and the eventual loss given delinquency, and they are stronger for mortgages originated after the NPA reclassification.

\section{Conclusion}

The Indian regulatory and macroeconomic environment has changed dramatically during the last two decades. A fast-developing housing finance system has coped with significant variation in default rates and interest rates, and regulatory changes in the incentives to originate mortgages in general, and small loans in particular. We have presented evidence that regulatory subsidies for low-cost housing distorted the efficient markets relationship between interest rates and subsequent delinquencies, and that changes to the definition of non-performing assets impacted behavior in response to early evidence of payment delinquencies. While it is difficult to generalize findings from one country, the latter results on the change in the regulatory definition of NPAs do suggest that even seemingly innocuous changes in regulatory definitions can have important impacts on mortgage monitoring and origination practices, and hence on mortgage risk.

We view our approach of linking time-variation in regulation with expected cross-sectional impacts on different types of mortgages as a potentially appealing alternative for studies analyzing the impacts of regulation on market outcomes, especially in situations where dis- 
continuities are hard to identify, or in environments where the discontinuities at thresholds are blurred by the responses of market participants. Overall, our paper contributes to the growing body of literature on the impacts of regulators and regulatory norms on risks in financial markets. 


\section{References}

Acharya, Viral V., Matthew Richardson, Stijn van Nieuwerburgh, and Lawrence J. White, 2011, Guaranteed to Fail: Fannie Mae, Freddie Mac, and the Debacle of Mortgage Finance, Princeton University Press, Princeton, NJ.

Adelino, Manuel, Kristopher Gerardi, and Paul S. Willen, 2009, "Renegotiating Home Mortgages: Evidence from the Subprime Crisis", unpublished paper, Federal Reserve Bank of Boston.

Agarwal, Sumit, Gene Amromin, Itzhak Ben-David, Souphala Chomsisengphet, and Douglas D. Evanoff, 2011, "The Role of Securitization in Mortgage Renegotiation”, Dice Center Working Paper 2011-2, Ohio State University.

Agarwal, Sumit, Nittai Bergman, Efraim Benmelech, and Amit Seru, 2012, Did the Community Reinvestment Act lead to Risky Lending?

Aghion, Philippe, Robin Burgess, Stephen J. Redding, and Fabrizio Zilibotti, 2008, "The Unequal Effects of Liberalization: Evidence from Dismantling the License Raj in India", American Economic Review, 98(4), 1397-1412.

Amromin, Gene, Jennifer Huang, Clemens Sialm, and Edward Zhong, 2011, "Complex Mortgages," unpublished paper, Federal Reserve Bank of Chicago and University of Texas at Austin.

Anagol, Santosh, and Hugh Kim, 2012, "The Impact of Shrouded Fees: Evidence from a Natural Experiment in the Indian Mutual Funds Market", American Economic Review, 102(1), 576-593.

Baily, Martin N., 2011, ed., The Future of Housing Finance: Restructuring the U.S. Residential Mortgage Market, Brookings Institution Press, Washington, DC.

Banerjee, Abhijeet, Shawn Cole, Esther Duflo, and Leigh Linden, 2007, "Remedying Education: Evidence from Two Randomized Experiments in India," Quarterly Journal of Economics, 122(3), 1235-1264. 
Besley, Tim, and Robin Burgess, 2000, "Land Reform, Poverty Reduction and Growth: Evidence from India", Quarterly Journal of Economics, 115 (2), 389-430.

Bhutta, Neil, Jane Dokko, and Hui Shan, 2010, "The Depth of Negative Equity and Mortgage Default Decisions," FEDS Working Paper 2010-35, Federal Reserve Board.

Campbell, John Y., 2012, "Mortgage Market Design", unpublished paper, Harvard University.

Campbell, John Y. and Joao F. Cocco, 2012, "A Model of Mortgage Default", unpublished paper, Harvard University and London Business School.

Campbell, John Y., Tarun Ramadorai, and Vimal Balasubramaniam, 2012, "Prudential Regulation of Housing Finance in India 1995-2011", regulatory appendix, available at: http://intranet.sbs.ox.ac.uk/tarun_ramadorai/TarunPapers/PrudentialRegulationAppendix.pdf.

Campbell, John Y., Tarun Ramadorai, and Benjamin Ranish, 2012, "Appendix to Campbell, Ramadorai, and Ranish", empirical appendix, available at: http://intranet.sbs.ox.ac.uk/tarun_ramadorai/TarunPapers/MortgageEmpiricalAppendix.pdf.

Campbell, Tim S. and J. Kimball Dietrich, 1983, "The Determinants of Default on Insured Conventional Residential Mortgage Loans", Journal of Finance 38, 1569-1581.

Cole, Shawn A., 2009, "Fixing Market Failures or Fixing Elections? Elections, Banks and Agricultural Lending in India", American Economic Journal: Applied Economics 1, $219-50$.

Dahl, Drew, Douglass Evanoff, and Michael Spivey, 2000, "Does the Community Reinvestment Act Influence Lending? An analysis of Changes in Bank Low-Income Mortgage Activity," Working Paper no.2000-06. Federal Reserve Bank of Chicago

Demyanyk, Yuliya, and Otto van Hemert, 2011, "Understanding the Subprime Mortgage Crisis", Review of Financial Studies, 24, 1848-1880. 
Duca, John V. and Stuart S. Rosenthal, 1994, "Do Mortgage Rates Vary Based on Household Default Characteristics? Evidence Based on Rate Sorting and Credit Rationing", Journal of Real Estate Finance and Economics 8, 99-113.

Ellis, Luci, 2008, "The Housing Meltdown: Why Did It Happen in the United States?", Bank for International Settlements Working Paper 259.

Foote, Christopher, Kristopher Gerardi, Lorenz Goette, and Paul Willen, 2010, "Reducing Foreclosures: No Easy Answers," NBER Macroeconomics Annual 2009, 89-138.

Hunt, Stefan, 2010, "Informed Traders and Convergence to Market Efficiency: Evidence from a New Commodity Futures Exchange", unpublished paper, Harvard University.

International Monetary Fund, 2011, "Housing Finance and Financial Stability - Back to Basics?", Chapter 3 in Global Financial Stability Report, April 2011: Durable Financial Stability - Getting There from Here, International Monetary Fund, Washington, DC.

Johnson, Kathleen W. and Geng Li, 2011, "Are Adjustable-Rate Mortgage Borrowers Borrowing Constrained?", FEDS Working Paper 2011-21, Federal Reserve Board, Washington, DC.

Kashyap, Anil, Raghuram Rajan, and Jeremy Stein, 2008, "Rethinking Capital Regulation", in Federal Reserve Bank of Kansas City Symposium on Maintaining Stability in a Changing Financial System, 431-471.

Keys, Benjamin, Tanmoy Mukherjee, Amit Seru, and Vikrant Vig, 2010, "Did Securitization Lead to Lax Screening? Evidence from Subprime Loans", Quarterly Journal of Economics 125, 307-362.

Kroszner, Randall, 2008, "The Community Reinvestment Act and the Recent Mortgage Crisis," speech at the Confronting Concentrated Poverty Policy Forum.

von Lilienfeld-Toal, Dilip Mookherjee and Sujata Visaria, 2012, "The Distributive Impact of Reforms in Credit Enforcement: Evidence from Indian Debt Recovery Tribunals", 
Econometrica, 89, 497-558.

Melzer, Brian T., 2011, "Mortgage Debt Overhang: Reduced Investment by Homeowners with Negative Equity", unpublished paper, Northwestern University.

Mian, Atif and Amir Sufi, 2009, "The Consequences of Mortgage Credit Expansion: Evidence from the U.S. Mortgage Default Crisis", Quarterly Journal of Economics 124, $1449-1496$.

Piskorski, Tomasz, Amit Seru, and Vikrant Vig, 2011, "Securitization and Distressed Loan Renegotiation: Evidence from the Subprime Mortgage Crisis", Journal of Financial Economics 97, 369-397.

Tiwari, Piyush and Pradeep Debata, 2008, "Mortgage Market in India", Chapter 2 in Danny Ben-Shahar, Charles Ka Yui Leung, and Seow Eng Ong eds. Mortgage Markets Worldwide, Blackwell.

U.S. Treasury and Department of Housing and Urban Development, 2011, Reforming America's Housing Market: A Report to Congress, Washington, DC.

Verma, R.V., 2012, "Evolution of the Indian Housing Finance System and Housing Market", Chapter 14 in Ashok Bardhan, Robert H. Edelstein, and Cynthia A. Kroll eds. Global Housing Markets: Crises, Policies, and Institutions, John Wiley.

Wooldridge, Jeffrey M., 2002, Econometric Analysis of Cross Section and Panel Data, MIT Press, Cambridge, MA. 